\title{
Long distance particle transport to the central Ionian Sea
}

Léo Berline ${ }^{1}$, Andrea Michelangelo Doglioli ${ }^{1}$, Anne Petrenko ${ }^{1}$, Stéphanie Barrillon ${ }^{1}$, Boris Espinasse ${ }^{2}$, 5 Frederic A.C. Le Moigne ${ }^{1}$, François Simon-Bot ${ }^{1}$, Melilotus Thyssen ${ }^{1}$, François Carlotti ${ }^{1}$

Correspondence to: Leo Berline (leo.berline@mio.osupytheas.fr)

\begin{abstract}
In the upper layers of the Ionian Sea, young Mediterranean Atlantic Waters (MAW) flowing eastward from the Sicily channel meet old MAW. In May 2017, during the PEACETIME cruise, fluorescence and particle content sampled at high resolution revealed unexpected heterogeneity in the central Ionian. Surface salinity measurements, together with altimetryderived and hull-mounted ADCP currents, describe a zonal pathway of AW entering the Ionian Sea, consistent with the socalled cyclonic mode in the North Ionian Gyre. The ION-Tr transect, located $\sim 19-20^{\circ} \mathrm{E}-\sim 36^{\circ} \mathrm{N}$ turned out to be at the crossroad of three water masses, mostly coming from the west, north and from an isolated anticyclonic eddy northeast of ION-Tr. Using Lagrangian numerical simulations, we suggest that the contrast in particle loads along ION-Tr originates from particles transported from these three different water masses. Waters from the west, identified as young AW carried by

20 a strong southwestward jet, were intermediate in particle load, probably originating from the Sicily channel. Water mass originating from the north was carrying abundant particles, probably originating from northern Ionian, or further from the south Adriatic. Waters from the eddy, depleted in particles and Chl-a may originate from south of Peloponnese, where the Pelops eddy forms.
\end{abstract}

25 The central Ionian Sea hence appears as a mosaic area, where waters of contrasted biological history meet. This contrast is particularly clear in spring, when blooming and non-blooming areas co-occur. Particle abundance in situ measurements are useful to discriminate water masses and derive circulation, together with T-S properties.

Interpreting the complex dynamics of physical-biogeochemical coupling from discrete measurements made at isolated stations at sea is a big challenge. The combination of multiparametric in situ measurements at high resolution with remote sensing and Lagrangian modeling appears as one proper way to address this challenge. 
https://doi.org/10.5194/bg-2020-481

Preprint. Discussion started: 25 January 2021

(c) Author(s) 2021. CC BY 4.0 License.

(c) (i)

\section{Introduction}

The Ionian Sea is a cross road where young modified Atlantic water (AW) flowing from the Sicily channel meets older MAW flowing from the East, and water coming from the Adriatic Sea (Malanotte-Rizzoli et al 1997). Circulation in the North Ionian, and thus the path of AW spreading, is variable and two alternate states have been proposed, the anticyclonic

35 and cyclonic mode of the so called North Ionian Gyre (NIG, Gačić et al 2010). The direction of the NIG has a strong influence on the dispersal of water masses and properties in the Ionian basin, also impacting its productivity (Lavigne et al 2018)..

Although the circulation in the Ionian basin has been documented according to seasons and NIG modes (Malanotte-Rizzoli et al 1997, Gačić et al 2011, Menna et al 2019), the fine scale pathways of AW crossing Ionian Sea have only been seldom

40 sampled. The contact zone between water masses can only be characterized through high resolution sampling, potentially revealing small scale horizontal discontinuities in properties missed by traditional coarse sampling.

Ionian Sea is generally considered oligotrophic (Boldrin et al 2002), with a north-south gradient of Chl-a (d'Ortenzio et Ribera d'Alcala 2009). However, it is not homogeneous, as distinct phytoplankton communities associated to the main water masses have been described (Casotti et al 2003). Three main phytoplankton communities were associated with water coming

45 from Adriatic in the north west, water from the Eastern Mediterranean in the north east and AW from Sicily channel to the south. Zooplankton community was also contrasted between northwestern and eastern Ionian (Mazzocchi et al 2003).

The influence of water masses on particle distribution is less described. Presently few data are available on the horizontal distribution of particles in the Ionian Sea. These data are mostly from transmissometry, bottle derived particulate matter filtration (Rabitti et al 1994, Boldrin et al 2002, Karageorgis et al 2008, 2012) and few data are from optical devices

50 (Ramondenc et al 2016).

The objective of this paper is to document an abrupt change in particle abundance along a high-resolution multi-parametric transect located at the boundary between water masses in the central Ionian Sea, to propose scenarios of histories of these waters masses and discuss implications.

\section{Material and Methods}

55 The PEACETIME cruise (http://peacetime-project.org/, Guieu et al 2020) was conducted during late spring conditions from May $10^{\text {th }}$ to June ${ }^{11}$ th, 2017 on board the R/V Pourquoi Pas ?. Along the $4300 \mathrm{~km}$ transect covering western and eastern Mediterranean basin, 10 short stations (with an average duration of 8 hours) and 3 long stations (duration of 4-5 days) were performed. The ship entered Ionian Sea on May $22^{\text {nd }}$ and the last station (ST8) in the region was occupied on May $30^{\text {th }}$ as detailed in table 1. 
https://doi.org/10.5194/bg-2020-481

Preprint. Discussion started: 25 January 2021

(c) Author(s) 2021. CC BY 4.0 License.

(c) (i)

60 At stations, Rosette casts were carried out (0-500 and 0-bottom). The "classical” Rosette was composed of a CTD (pressure, temperature and salinity of seawater, dissolved oxygen concentration, photosynthetically active radiation (PAR), beam transmission (at $650 \mathrm{~nm}$ ), chlorophyll a fluorescence. This instrumental package was also composed of a sampling system : 24 12-L Niskin bottles could be fired at specified levels during upcasts. Water from the classical Rosette was used to quantify oxygen, nutrients, Dissolved Organic Carbon, Particulate Organic Carbon and Nitrogen and pigments using HPLC

65 (see Guieu et al 2020, and Marañón et al 2020 for detail on HPLC).

\subsection{High resolution vertical sampling}

Between stations, transects with a Moving Vessel Profiler (MVP) were carried out. In the Ionian Sea two transects were achieved, ION-Tr and a very short ST8-Tr (figure 1). MVP200 ODIM Brooke Ocean performed vertical profiles, at a spatial resolution of $\sim 1 \mathrm{~nm}$, with the nearly vertical free falls of the Multi Sensor Free Fall Fish type I equipped with a AML

70 microCTD, a WetLab ECO fluorimeter, and a ODIM Brooke Ocean Laser Optical Plankton Counter (LOPC). The T and S of the microCTD were calibrated with the rosette CTD. The LOPC recorded particle size and abundance distributions: the instrument records the cross-sectional area of each particle passing through its laser beam (Herman et al., 2004; Herman \& Harvey, 2006) for a size range between $100 \mu \mathrm{m}$ and a few centimeters. If a particle is recorded by at least 3 diode elements, it will be recorded as a multi-element plankton (MEP), in contrast to single element plankton (SEP). LOPC also provides

75 information about the MEPs allowing to compute an attenuance index (AI). The living fraction of particles can be estimated, using a calibration based on comparison with plankton net tows (Espinasse et al., 2018). The sampling volume was estimated using the LOPC sampling tunnel surface multiplied by the depth increment estimated with the pressure sensor. Given the fish free-fall velocity of $\sim 4 \mathrm{~m} / \mathrm{s}$ and the LOPC acquisition frequency ( $2 \mathrm{~Hz}$ ), we binned the LOPC over 5-m vertical bins. As the surface docking depth of the MVP fish was not constant, the first bin (0-7.5 m) was discarded from the analysis. The

80 LOPC abundances were redistributed into log-scale size bins for easier analysis. Total abundance (e.g., abundance over the full LOPC size range) and parameters of the size distribution were computed (slope and intercept of the Normalized Biomass Size Spectra (NBSS), e.g. Espinasse et al., (2018). We thus have access to vertical profiles of total abundance of particles (particles per cubic meter) at almost each kilometer during the MVP transects.

\subsection{Underway measurements}

85 The TSG, equipped with a SeaBird SBE21, was connected to a continuous surface water flow-through system that pumped seawater at 2-m depth. Output data were sea surface temperature and Salinity every minute all along the cruise route. Horizontal velocity was measured with a hull mounted ADCP.: RDI Ocean Surveyor 150kHz. Data treatment used CASCADE software version 7.1 (Le Bot et al 2011) and LATEXtools toolbox (Petrenko et al., 2017, Doglioli et al., 2013, https://people.mio.osupytheas.fr/ doglioli/latextools.htm). 
https://doi.org/10.5194/bg-2020-481

Preprint. Discussion started: 25 January 2021

(c) Author(s) 2021. CC BY 4.0 License.

(c) (i)

\section{$90 \quad 2.3$ Automated cytometry}

Surface phytoplankton community was analysed using an automated flow cytometer (Cytosense benchtop flow cytometer from CytoBuoy b.v) installed on a dedicated continuous sampling system set up to pump surface water (at $5 \mathrm{~m}$ depth). The Cytosense automated flow cytometer was equipped with a $120 \mathrm{~mW}, 488 \mathrm{~nm}$ laser beam. The volume analyzed was controlled by a calibrated peristaltic pump and each particle passed in front of the laser beam at a speed of $2 \mathrm{~m} \cdot \mathrm{s}^{-1}$. The

95 particle resolved size range varied from $<1 \mu \mathrm{m}$ up to $800 \mu \mathrm{m}$ in width and several hundreds of $\mu \mathrm{m}$ in length for chain forming cells. The trigger to record a signal was based on pigment fluorescence. Stability of the optical unit was controlled before and after the cruise using fluorescing $2 \mu \mathrm{m}$ Polyscience beads, and a set of silica beads of 1.0 , 2.0 ,3.0, 5.0, 7.0 $\mu \mathrm{m}$. The size estimates of cells were retrieved from the silica beads FWS signature, and enabled to separate pico-nanomicrophytoplankton size classes. The instrument allowed for the quantification of pico-, and nanophytoplankton populations, up to microphytoplankton when abundant enough in the $5 \mathrm{~mL}$ analyzed. Seven groups were resolved. One group of picoeukaryotes (mean size 2.81 $\pm 0.19 \mu \mathrm{m}$ ), three groups of nanoeukaryotes (Nanoeukaryotes1, 2 and 3, mean sizes of 4.76 $\pm 0.13,7.16 \pm 0.35$ and $10.64 \pm 2.18 \mu \mathrm{m}$ respectively), Synechococcus like (1.04 $\pm 0.12 \mu \mathrm{m})$, Chryptophytes like (6.00 $\pm 0.93 \mu \mathrm{m})$ and a coccolitophore like group $(5.37 \pm 0.14 \mu \mathrm{m})$. Each phytoplankton group was manually clustered thanks to the Cytoclus ${ }^{\circledR}$ (http://www.cytobuoy.com/products/software/) dedicated software.

\subsection{Satellite data}

Several remote sensing datasets were exploited using the SPASSO (Software Package for an Adaptive Satellite-based Sampling for Ocean campaigns, https://spasso.mio.osupytheas.fr/; last access: 2 Oct. 2020). Altimetry data was obtained from the AVISO Mediterranean regional product. Delayed-time L4 maps of SST Sat (Mediterranean Sea - High Resolution L4 SST Reprocessed; Nardelli et al., 2013; Pisano et al., 2016) and Chl Sat a (Mediterranean Sea Reprocessed Surface

110 Chlorophyll Concentration from Multi Satellite observations) were retrieved for the period of the cruise, on regular grids of $0.04 \times 0.04 \circ$ resolution for SST Sat and of $1 \times 1 \mathrm{~km}$ resolution for Chl Sat a from CMEMS - Copernicus Marine Environment Monitoring Service (http://marine.copernicus.eu/). SPASSO provided several Lagrangian diagnostics of the altimetry-derived current field, such as the Finite scale Lyapunov Exponent (FSLE) computed using the algorithm of d'Ovidio et al. (2004), in order to help in positioning the sampling transect and stations taking into account the ocean 115 dynamics. This approach was successfully adopted during previous cruises such as LATEX (Petrenko et al, 2017), KEOPS2 (d'Ovidio et al., 2015), OUTPACE (Moutin et al, 2017).

\subsection{Lagrangian numerical simulations}

In order to estimate the origins of the sampled surface water along transect ION-Tr, the ARIANE package (Blanke and Raynaud, 1997) was used to predict surface trajectories of water particles, using surface geostrophic velocities derived from 
https://doi.org/10.5194/bg-2020-481

Preprint. Discussion started: 25 January 2021

(c) Author(s) 2021. CC BY 4.0 License.

(c) (i)

Environment Marine Service (CMEMS) were used, with a resolution of $1 / 8^{\circ}$, using the near real time data, validated by an accurate comparison with both the hull-mounted ADCP-data and the SVP drifters deployed during the cruise (Barrillon et al 2019). The numerical particle positions were initialized in a polygon around the ship’s track on May 29 (longitude:18-20.1, latitude: $35.4-35.9,+-0.2^{\circ}$ in latitude). This polygon takes into account possible offset between in situ velocity and satellite 125 derived geostrophic velocity. Given the daily time series of the surface velocity field, the ARIANE package computes numerical particle trajectories through a backward or forward integration time. The so-called "qualitative" mode is chosen: each particle trajectory can be followed step by step through the integration time. Only surface trajectories were considered. 10000 particles chosen randomly inside the launch area were advected backward for one month. This duration was chosen as a trade-off between source identification and error accumulation along the trajectories. The particle trajectories and final positions were analyzed to determine the main source areas.

The cruise data are available on LEFE-CYBER database.

\section{Results}

\subsection{Oceanographic context}

135 Time series of satellite Chl-a showed that surface phytoplankton concentration was decaying since mid-March (figure 2). Since the end of April, the Ionian Sea was steadily warming while Chl-a concentration remained low (0,09 mg. $\left.\mathrm{m}^{-3}\right)$ indicating the absence of significant surface production events. On average over April-May, maximum Chl-a concentrations were observed in the area South of the Strait of Messina and in the Gulf of Taranto (not shown).

140 At the end of May in the Ionian basin, satellite imagery (figures 3A and 3B) shows a slight large scale meridional gradient of SST and Chla, with warmer and low-Chl water to the south and colder and medium Chl-water to the north. In addition, a strong variability was observed at the mesoscale with cold and Chl-rich filaments south of the Strait of Messina and south of Sicily, extending toward the center of the basin. Several cyclonic and anti-cyclonic structures were visible in the center of the basin.

The along route salinity showed a general increase toward the east and the north. On the northern part of the route (SAVST7-ION), there was a transition from medium salinity to the north to low then high salinity at the easternmost end of the route close to long duration station ION. On the southern part of the route (ION to ST8), there was an alternation of low and high salinity water, sampled during ION-Tr transect. Then west of $18^{\circ} \mathrm{E}$, salinity was stable lower than 38.2 up to the Sicily 150 channel. Therefore SAV and ST7 were in medium salinity waters, ION (ST8) was in high (low) salinity waters, while IONTr crossed waters with contrasted salinities. 
https://doi.org/10.5194/bg-2020-481

Preprint. Discussion started: 25 January 2021

(c) Author(s) 2021. CC BY 4.0 License.

(c) (i)

The two cytometric groups showing contrasted distribution and sufficient abundance are shown (figures 3C and 3D). In the Ionian Sea, nanoeukaryotes1 and coccolithophore like showed a distribution consistent with salinity, with higher values in saltier water except southeast of Sicily. The pattern was also mostly consistent with satellite Chl-a, with high abundances southeast of Sicily and south of the Strait of Messina. However, along ION-Tr, abundance was variable while satellite Chl-a was fairly constant.

Altimetry-derived surface geostrophic current showed a general circulation with an anticyclonic flow across the basin (figure 4A). South of Sicily, water entered the Ionian Sea around $36^{\circ} \mathrm{N}$ along a southeastward path, progressed eastward along $35.5^{\circ} \mathrm{N}$, then veered southwestward close to $19.5^{\circ} \mathrm{E}$. East of $18^{\circ} \mathrm{E}$, the currents show a pattern consistent with the intense $(\sim 0,5 \mathrm{~m} / \mathrm{s}$ ) currents measured by the hull-mounted ADCP along the ship route, depicting an anti-cyclonic meander, more intense on its eastern flank. There is a small spatial offset between altimetry and ADCP $\left(\sim 0.4^{\circ}\right.$, figure $\left.4 \mathrm{~B}\right)$. The southwestward branch of this meander was located approximately in the center of the ION-Tr transect, while the ION station

165 was located on the eastern border of the meander. Altimetry-derived FSLE field (figure 3), as well as the time series of ADT (annex A) showed that this anticyclonic meander east of $18^{\circ} \mathrm{E}$ was stable during May. The southwestward jet sampled during ION-Tr coincided with a slightly cooler and higher Chl-a filament than surrounding waters, as shown on figures 3A and 3B.

\subsection{Distribution of properties along transect ION-Tr}

Based on the salinity distribution (figure 5), ION-Tr can be divided into three parts. From West to East, a western part (noted 170 W) with salinity $>39$, except the fresher top layer 0-30m, a center part (noted C) with a low salinity vein (<38.7) extending to 70m deep, and an eastern part (noted E) with quasi-homogeneous salinity on the vertical, slightly lower than in W (39). Hereafter we define three pseudo-stations along ION-Tr, named ION-W, ION-C, ION-E. Note that ION long duration station was located very close to the eastern part of ION-Tr (figure 1), thus ION-E and ION can be approximated as a single station.

This salinity distribution coincided with pattern of ADCP currents magnitude, with ION-W and ION-E being in quiescent 175 water (current $<0.2 \mathrm{~m} / \mathrm{s}$ ), while ION-C correspond to a strong $(>0.3 \mathrm{~m} / \mathrm{s}$ ) southwestward jet extending from the surface to $300 \mathrm{~m}$ depth. The total abundance of particles, as well as Chl-a fluorescence clearly contrasted between ION-W and ION-E. In ION-W, particle abundance was low $\left(<510^{4} \# \cdot \mathrm{m}^{-3}\right)$, essentially concentrated within the $20-30 \mathrm{~m}$ layer. Fluorescence was rather homogeneous with a broad maxima around 110m. In ION-E part, abundance was much higher $\left(>210^{4} \# \cdot \mathrm{m}^{-3}\right)$ with a deep maximum at $100 \mathrm{~m}$ depth (values around $110^{5} \mathrm{H} \cdot \mathrm{m}^{-3}$ ) close to the depth of the Deep Chlorophyll Maximum (DCM) and also high particle abundance in the upper 20-90m layer $\left(\sim 310^{4} \mathrm{H} \cdot \mathrm{m}^{-3}\right)$. ION-C was distinct from ION-E and ION-W in term of vertical distribution and abundance of particle as well as fluorescence, with the low salinity vein coinciding with higher particle abundance and the maximum fluorescence being located ca $70 \mathrm{~m}$, at the interface between low salinity waters and underlying waters. 
https://doi.org/10.5194/bg-2020-481

Preprint. Discussion started: 25 January 2021

(c) Author(s) 2021. CC BY 4.0 License.

(c) (i)

185 The T-S distribution of ION-Tr (figure 6) mirrored the distributions of stations ST8 and ION. Water at ION-C is similar to ST8 for densities greater than 1028 (ie deeper than 25m). ION-E is similar to ION with more scatter. ION-W does not match the other stations. Northern stations ST7 and SAV had similar water masses properties, distinct from ST8, ION and the IONTr profiles.

At the surface, cytometric groups also showed contrasting abundances along ION-Tr (figures 3C and 3D). Horizontal 190 sampling resolution did not allow to distinguish ION-C region. From west to east with respect to ION-C, nanoeukaryotes1 increased from low values (as mean $\pm \mathrm{SD}, 487 \pm 52$ cells.cm $\left.^{-3}, \mathrm{n}=27,18-19.5^{\circ} \mathrm{E}\right)$ to higher values $\left(659 \pm 50 \mathrm{cells}^{\mathrm{c}} \mathrm{cm}^{-3}, \mathrm{n}=117\right.$, $>19^{\circ} 5 \mathrm{E}$ ). Coccolithophore like group also increased (176 \pm 18 cells.cm ${ }^{-3}$ against $192.47 \pm 13$ cells.cm ${ }^{-3}$ ). Conversely, picoeukaryotes abundances decreased eastward (653 \pm 94 cells.cm ${ }^{-3}$ vs $462.8 \pm 76$ cells.cm ${ }^{3}$, not shown). The other groups did not evidence high changes in abundances.

\subsection{Comparison of vertical distribution across stations}

Carousel measurement performed at the SAV, ST7, ST8 stations together with the one from the ION transect are shown in figure 7. These vertical profiles allow a finer analysis of the contrast between stations and among parts of ION-Tr. Consistent with figure 6, Salinity increased from ST8 to ION-E. If we take apart the upper 0-25m depth corresponding to the mixed layer (ML), couples of stations were similar: ION-C and ST8, ION-E and ION-W, ST7 and SAV. A narrow $(<10 \mathrm{~m}$ thick), lower salinity layer was present at 30m on every profile except ION-E. The surface pycnocline was located at 10 to $25 \mathrm{~m}$, followed by a steep thermocline down to $60-80 \mathrm{~m}$. Surface nitrate was depleted everywhere. Nitracline depths increased from $60 \mathrm{~m}$ at SAV up to $90 \mathrm{~m}$ at ION, together with nitrate concentrations below the euphotic zone.

DCM was always present, but its intensity was highest at ST8 and lowest at ION-W and ION-C, where fluorescence was more diluted. The depth of DCM corresponded to the top of nitracline and to the bottom of the euphotic zone ( 90m at ION).

205 Profiles of particle abundance were strongly variable among stations. The depth-integrated abundance was highest at SAV and lowest at ION-W. Some profiles had several maxima. At ST8 and ION-E, the main peak was just above the DCM depth, and a secondary peak was present above DCM at $\sim 20 \mathrm{~m}$, also present at ION-W. SAV profile was different with a large peak at $50 \mathrm{~m}$, above DCM, and a surface peak at $10 \mathrm{~m}$.

210 Considering particle parameters (table 2), the slopes of the NBSS were similar for stations ST8, ION-W, ION-C $(0,92)$, and slightly lower for SAV and ION-E $(0,85)$, indicating more abundant larger particles. On a depth average, referring to the calibration given in Espinasse et al (2018), MEP proportion indicated that at ION-C and ION-W, particles counted were $60 \%$ zooplankton, while at ION-E, ST8 and SAV particles were mainly detritus ( 75-90\%) ie non-living particles such as aggregates produced after intense primary production. AI was similar across depth layers but higher at ION-E (0.1 against 2150.05 and 0.08), while MEP was more abundant in the 50-150m layer, where the particle maxima were observed. 
https://doi.org/10.5194/bg-2020-481

Preprint. Discussion started: 25 January 2021

(c) Author(s) 2021. CC BY 4.0 License.

(c) (i)

\subsection{Origin of particles}

Lagrangian simulations showed that the water parcels observed along ION-Tr originate from four main regions (figure 8). One located south, one located west and two located north of ION-Tr. As the altimetry-derived velocity was shifted $\sim 0.4^{\circ}$ west with respect to in-situ velocity from ADCP (figure 4B), the initial positions of numerical particles were extended westward to $18^{\circ} \mathrm{E}$. Considering the main pathways of particles, four source regions can be defined (South origin So, West origin Wo, North origin No, Eddy origin Eo). Along ION-Tr, the proportion of each origin region showed a rather clear pattern, with some overlap in the center (figure 8F). Referring to the three parts identified along ION-Tr, ION-W was in waters mainly originating from Eo. ION-C was mainly originating from Wo but also from Eo and to a lesser extent from So. ION-E was only originating from No. Finally, west of $18.6^{\circ} \mathrm{E}$, beyond the limit of the actual transect, So was the main contributor.

\section{Discussion}

\subsection{Surface circulation and distribution of water masses in the Ionian Sea}

Surface circulation, together with the along track surface salinity distribution, describe one pathway of MAW penetrating into Ionian Sea (figures 3 and 4). Here, this pathway is approximately zonal along latitude $36^{\circ} \mathrm{N}$ from the Sicily Strait up to

$23019^{\circ} \mathrm{E}$, then veering southwestward. This pathway is supported by the similarity of water masses properties sampled at ST8 and ION-C (figures 6 and 7) and illustrated by backtracked trajectories (figure 8, Western origin), indicating a $c a$ one month travel between $15^{\circ} \mathrm{E}$ and $19.5^{\circ} \mathrm{E}$. It is also supported by the absence of transport barriers east of ST8 shown by FSLE (figure 3). North of $36^{\circ} \mathrm{N}$, the similarity of ST7 and SAV water masses properties (figure 6) also supports a single origin of water masses in the Northern Ionian.

This distribution of MAW in the Ionian Sea is consistent with a cyclonic mode of the so called North Ionian Gyre (NIG, Gačić et al 2010), that characterizes the circulation in the Ionian Sea north of $c a 35.5^{\circ} \mathrm{N}$. In the cyclonic mode of the NIG, MAW follows a rather direct East-SouthEast path, while saline water from the Levantine basin enters the Northern Ionian Sea from the East, and current flows southwestward along Calabria (Menna et al 2019). As observed by altimetry, the NIG 240 was cyclonic since 2011 (Menna et al 2019), and reversed to anticyclonic in the second half of 2017 (von Schuckmann et al., 2019), after our sampling.

It is interesting to note that the southwestward jet sampled along ION-Tr is a persistent feature of Ionian Sea circulation, generally located at $\mathrm{ca} 20^{\circ} \mathrm{E}, 36^{\circ} \mathrm{N}$ and directed southward (see figure 2 in Menna et al 2019, Celentano et al 2020, Berline et 245 al 2014). It is present during cyclonic and anticyclonic modes of the NIG. It pertains to the northern branch of the Mid Ionian Jet (MIJ). 
https://doi.org/10.5194/bg-2020-481

Preprint. Discussion started: 25 January 2021

(c) Author(s) 2021. CC BY 4.0 License.

(c) (i)

Cyclonic circulation of the NIG implies a downwelling of nutricline at the northern border of the NIG, and an upwelling of nutricline in the central NIG (Civitarese et al 2010, Lavigne et al, 2018). Our observations of nutricline depth (isoline $1 \mu \mathrm{M}$ at $\sim 55 \mathrm{~m}$ for SAV and $\sim 95 \mathrm{~m}$ for ST8) are consistent with the shallow nutriclines during cyclonic mode shown by Lavigne et al, (2018). Cyclonic mode also favors higher Chl-a in the center NIG, and a late winter bloom (Lavigne et al, 2018). However the Chl-a evolution over 2017 only shows a weak bloom in the Northern Ionian (figure 2). This may result from a weak winter buoyancy loss, independent of the NIG circulation, as pointed out by Lavigne et al (2018). The last increase of Chl-a occurred in the last week of April 2017, then Chl-a decreased and reached its minimum value around the end of May, during 255 our sampling.

\subsection{Origin of water masses sampled along ION-Tr}

In the center of ION-Tr, a strong current is associated to a low salinity vein (down to 38.4, figure 6). The center current dynamically separates the two parts of the transect, and this separation is stable as supported by the FSLE ridge (figure 3). While the density stratification is similar along the transect, particle and Chla distributions show a striking difference from $\mathrm{E}$ 260 to W. At ION-E, there is 60\% higher particle abundance, and twice higher biovolume compared to ION-W (table 2), essentially due to particles with and equivalent spherical diameter (ESD) smaller than $500 \mu \mathrm{m}$. At ION-E particles are filling the pycnocline from 1028 to $1028.7 \mathrm{~kg} . \mathrm{m}^{-3}$, with a maximum associated to a narrow DCM at 100m, while at ION-W particles are only present in the density layer 1028-1028.2, and the DCM is broad and weak, not associated to a particle peak.

265 The distinct Chl-a and particle distributions along ION-Tr suggest that waters sampled at ION-E and ION-W have distinct histories of biological production. One hypothesis is that these water masses originate from distinct locations. To explore this hypothesis, backtracking of particle trajectories was carried out and led to three main origins of water sampled along ION-Tr (Wo, No and Eo, as So is only marginally contributing to the transect), that correspond to different part of the transect (figure 8). When two origins overlap, we only consider the dominant origin. Water found at ION-C would be transported from the

270 West (Wo), ie the Sicily channel, while water found at ION-E (ION-W) would be transported mostly from the Northern Ionian (No), and from an eddy located North (Eo) respectively. Referring back to the general circulation in the Ionian, the ION-Tr appears to be at the crossroad between waters from the North Ionian, waters from the MIJ coming from the West and waters trapped into an anticyclonic eddy.

\subsection{Biological history of water masses sampled along ION-Tr}

275 LOPC detects particles of ESD >100 $\mu$ m (median ESD was 130-145 $\mu \mathrm{m}$ along ION-Tr), typically aggregates formed as a result of intense primary production (Briggs et al., 2020; Martin et al., 2011). Once produced, aggregates can fragment or coagulate, be grazed, be degraded by bacteria attached to them and sink out of the surface layer (Le Moigne 2019, 
https://doi.org/10.5194/bg-2020-481

Preprint. Discussion started: 25 January 2021

(c) Author(s) 2021. CC BY 4.0 License.

(c) (i)

Stemmann et al 2004). Therefore the particle abundance in the euphotic layer generally peaks shortly after a primary production event, then decreases with a speed depending on several factors.

Although the age of particles cannot be determined from their size distribution, we can make some hypothesis. At the time of sampling, the whole Ionian Sea was stratified, mixed layer was shallow $(\sim 25 \mathrm{~m})$ and nitrate was fully depleted over the euphotic zone except at SAV, indicating stable, post-bloom conditions. As surface Chl-a continuously decreased since the end of April (figure 2), this suggests that the last surface primary production event around ION station occurred about a month before our sampling. This is longer than the time lag observed between primary production and subsequent export in large mesocosms experiments (Stange et al., 2017). Therefore, freshly formed particles are not likely.

The sinking speed of particles depends on their mineral composition (Le Moigne 2013), shape (Laurenceau et al., 2019) and on the phytoplankton community (Riley et al 2012, Guidi et al 2009). Consistent with our cytometric results, the pigment composition available at ST7, ST8 and ION show a community dominated by nanophytoplankton (>60\% of total Chl-a) in the upper 80m, while diatoms were abundant at DCM depth (41-51\% of total Chl-a, see Marañón et al 2020). The dominance of nanophytoplankton and coccolithophores were also found by Boldrin et al (2002) in the Northern Ionian Sea $\left(38,5^{\circ} \mathrm{N}\right)$. Thus, in the upper $80 \mathrm{~m}$ small cells (typically $<5 \mu \mathrm{m}$ in diameter) do not favor the production of large aggregates and direct export (Richardson and Jackson 2007), conversely to DCM.

Second, aggregates are slowed down by density gradients, because of the equilibration time of their interstitial water (MacIntyre et al 1995, Prairie et al 2015). Therefore pronounced stratification can locally increase their abundance, as reported in numerous settings (Espinasse et al 2014, Marcolin et al 2013, Ohman et al 2012). This explains that all profiles have a particle peak at the main density gradient, just below the mixed layer depth (figure 7). However, this mechanism does not explain deeper peaks observed at 60m and 90m.

Finally, zooplankton can also contribute to the particle production through fecal pellet, and transformation (sloppy feeding), but we are lacking zooplankton abundance data for ION-C and ION-W.

305 We now review the potential processes that led to the observed particles and Chl-a distributions along ION-Tr, from west to east.

\subsubsection{Western part}

At ION-W, below the weak particle peak (figure 7, $210^{4} \# \cdot \mathrm{m}^{-3}$ ) associated with the density gradient at the bottom of the mixed layer, abundances steeply decrease and reach minimum values at $80 \mathrm{~m}\left(10^{4} \mathrm{\#} . \mathrm{m}^{-3}\right)$. Such a low particle abundance in 
https://doi.org/10.5194/bg-2020-481

Preprint. Discussion started: 25 January 2021

(c) Author(s) 2021. CC BY 4.0 License.

(c) (i)

310 the top 100m was not observed anywhere else across all PEACETIME LOPC profiles ( 800 casts, Guieu et al, 2020). The Chl-a concentration is also lower and very patchy compared to ION-E. As nitracline depth was shown to be highly correlated with the depth of the 1028,9 isopycnal in the Ionian (Lavigne et al 2018), the steep deepening of this isopycnal from ION-E to ION-W suggests a much deeper nutricline at ION-W than at ION-E (figure 5). Together, these observations emphasize the very oligotrophic character of station ION-W. Considering the backward trajectories (figure 8), this low abundance may result from two origins (i) waters trapped into an anticyclonic eddy (Eo), or (ii) waters from the southern Ionian (So), which is more oligotrophic and where phytoplankton concentration peak earlier in the year (D’Ortenzio and Ribera d'Alcala 2009). For hypothesis (i), analysis of the evolution of altimetry (annex A) revealed that the eddy stayed coherent during the first six months of 2017 while slowly moving from the eastern Ionian. This eddy may have trapped waters from the eastern Ionian, more oligotrophic (Casotti et al 2003), and the vertical velocities in the center of the anticyclonic eddy may have accelerated the export of particles, as observed in the eastern Mediterranean (Waite et al 2016). For (ii), particles profiles in the southern Ionian obtained with UVP in July 2008 (Picheral et al 2010) (ecotaxa.obs-vlfr.fr, Kiko et al 2020) did not show such low abundances, therefore not supporting this hypothesis.

\subsubsection{Center part}

At ION-C, the backtracked trajectories indicate two overlapping origins (Eo and Wo mainly). However the low salinity vein 325 extending down to $70 \mathrm{~m}$ is a clear footprint of AW observed at ST8. Given the distribution of surface salinity from TSG (figure 3A and 3B) this gives more support to Wo. As with ION-E, significant particles abundance above DCM suggest that particles were produced upstream, near ST8 or further west, possibly in the enriched area south of Sicily, then advected to central Ionian.

\subsubsection{Eastern part (ION station)}

330 At ION-E DCM, microphytoplankton was dominant (Marañón et al 2020). The DCM was associated to the bottom of the euphotic zone ( $\sim 90 \mathrm{~m}$ at ION), but not to a density gradient. Therefore the particle peak associated with DCM probably result from aggregates produced locally, from diatoms decay and fecal pellet production by zooplankton. Association of DCM with a particle peak was not observed in similar settings (see station A in Espinasse et al 2018), which suggests that the plankton community at ION-E DCM enhances aggregate production, perhaps through mucous production, as mucous was reported in sediment traps in the Northern Ionian (Boldrin et al 2002).

Above DCM, significant particle abundance $\left(2-3 \quad 10^{4}\right.$ \#.m $\mathrm{m}^{-3}$ ) was observed together with phytoplankton dominated by nanophytoplankton (Marañón et al 2020). This significant particle abundance above DCM is also observed at SAV and ST8, with much higher peak concentration at SAV than at ST8 (1.5 $10^{5} \# \cdot \mathrm{m}^{-3}$ and 3-4 $10^{4} \# . \mathrm{m}^{-3}$ resp). When particles are suspended or sink slowly with respect to the horizontal velocity, particle abundance act as tracer for horizontal advection 
https://doi.org/10.5194/bg-2020-481

Preprint. Discussion started: 25 January 2021

(c) Author(s) 2021. CC BY 4.0 License.

(c) (i)

(e.g. Karageorgis et al 2012, Chronis et al 2000). We argue that at stations SAV, ST8 as well as at ION-E, the abundance of particles above DCM is a remainder of past surface production event that has not been exported out of the surface layer yet. In the Northern Ionian, a POM maximum above DCM (0-50m) was also reported by Rabitti et al (1994), and attributed to relict bloom. As above DCM waters are depleted in nutrients, above-DCM particles at ION-E could be transported from an area where phytoplankton production was more intense and shallower, such as SAV according to the backward trajectories and the vertical profiles. This continuity is supported by the similar slope of the particle size spectra at SAV and ION-E (table 2). It is also supported by the higher surface abundance of cytometric counts of nanoeukaryotes and coccolithophores at SAV, along Calabria and at ION-E with respect to the other parts of the route (figures 3C, 3D). During transport from SAV to ION-E, particle abundance above DCM may have decreased because of the processes mentioned earlier.

In the upper 0-90m layer, nutrients were depleted and nanophytoplankton was dominant. Nanoeukaryotes abundances were stable during the five days of occupation of ION station, according to cytometric counts (not shown). This implies an active nutrient recycling, probably linked to the particle associated microbial community, also supported by the high bacterial production in the layer 0-100m reported by Marañón et al (2020) at ION.

355 ION-E particle characteristics are closest to the 'continental shelf' habitat type as defined by Espinasse et al (2014), in the Gulf of Lion in early May. The integrated particle abundance is about half $\left(18,710^{3} \# / \mathrm{m}^{2}\right.$ vs $\left.3810^{3} \# / \mathrm{m}^{2}\right)$, the average AI is lower $(0,08$ vs 0,2$)$, the $\% \mathrm{MEP}$ is higher (6 vs 1,8$)$, and the NBSS slope is similar but steeper $(0,85$ vs 0,79$)$. Zooplankton abundance was slightly higher (300 $10^{3} \mathrm{ind} / \mathrm{m}^{2}$ vs $20610^{3} \mathrm{ind} / \mathrm{m}^{2}$, see Feliu et al 2020, but this value may be biased high due

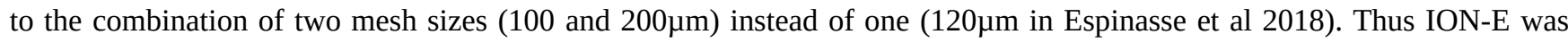
characterized by porous aggregates, with a rather high contribution of large aggregates (\%MEP).

Taking into account Chl-a, nanophytoplankton abundances, significant particle load above DCM and high bacterial production, ION station was not strongly oligotrophic, possibly under the influence of particles transported from North Ionian.

\section{Conclusions}

365 High resolution sampling of water masses, including fluorescence and particle contents revealed unexpected heterogeneity in the central Ionian Sea. Surface salinity measurements, together with altimetry and ADCP currents, describe a zonal pathway of AW entering into Ionian Sea, consistent with the cyclonic mode of the North Ionian Gyre. The ION-Tr appears precisely located at the crossroad of three water masses, coming from the West, North and from an isolated anticyclonic eddy. Water mass originating from the north carried abundant particles, probably originating from North Ionian, or further from the 370 Adriatic. Waters from the eddy were depleted in particles, and probably nutrients, and may originate from the Pelops eddy 
https://doi.org/10.5194/bg-2020-481

Preprint. Discussion started: 25 January 2021

(c) Author(s) 2021. CC BY 4.0 License.

(c) (i)

area, south of Peloponnese. Waters from the West, carried by a strong jet, were intermediate in particle load, probably originating from the Sicily channel, carried by AW.

Even away from the coasts, the central Ionian Sea appears as a mosaic area, where waters of contrasted biological history meet. ION station is potentially influenced by particles transported from the North Ionian Sea. This contrast is probably amplified in spring, when blooming and non-blooming areas co-occur. Long distance particle transport appears as a significant contribution to particulate matter load, together with atmospheric input.

The small scale heterogeneity of particle abundance revealed here emphasizes the spatial decoupling between particle production and particle distribution. Such decoupling added to the time lag between production and export of particles (Stange et al 2017) may have large impact on assessing the efficiency of carbon export from the surface ocean (Henson et al 380 2011). This also implies that neutrally buoyant particles can sustain production away, further horizontally and to deeper depths. Interpreting the complex dynamics of physical-biogeochemical coupling from discrete measurements made at isolated stations at sea is a big challenge. The combination of multiparametric in-situ measurements at high resolution with remote sensing and Lagrangian modeling appears as one proper way to address this challenge.

\section{Author contribution}

385 LB : Conceptualization, Writing - original draft preparation, Formal analysis, AD, AP, SB, BE, FLM, FSB, FC, MT: Formal analysis, Writing - review \& editing.

\section{Acknowledgments}

This study is a contribution to the PEACETIME project (http://peacetime-project.org), a joint initiative of the MERMEX and 390 ChArMEx components supported by CNRS-INSU, IFREMER, CEA, and Météo-France as part of the programme MISTRALS coordinated by INSU. PEACETIME was endorsed as a process study by GEOTRACES. PEACETIME cruise https://doi.org/10.17600/17000300. JL Fuda is thanked for his help on CTD calibration.

\section{References}

Barrillon S., Rousselet L., Petrenko A.A., Doglioli A., Lagrangian study of the water masses dynamics at the stations of the 395 PEACETIME cruise in the Mediterranean Sea. 7th LAPCOD Meeting. Venice, Italy. 17-21 June 2019.

Berline L, Rammou A-M, Doglioli A, Molcard A, Petrenko A A Connectivity-Based Eco-Regionalization Method of the Mediterranean Sea. PLoS ONE 9(11): e111978. doi:10.1371/journal.pone.0111978 2014 
https://doi.org/10.5194/bg-2020-481

Preprint. Discussion started: 25 January 2021

(c) Author(s) 2021. CC BY 4.0 License.

\section{(c) (1)}

Blanke, B., \& Raynaud, S. Kinematics of the Pacific equatorial undercurrent: An Eulerian and Lagrangian approach from GCM results. Journal of Physical Oceanography, 27(6), 1038-1053. 1997.

Boldrin, A., Miserocchi, S., Rabitti, S., Turchetto, M. M., Balboni, V., \& Socal, G. Particulate matter in the southern Adriatic and Ionian Sea: characterisation and downward fluxes. Journal of Marine Systems, 33, 389-410. 2002.

Briggs, N., Dall'Olmo, G., Claustre, H.,. Major role of particle fragmentation in regulating biological sequestration of CO2 by the oceans. Science (80-. ). https://doi.org/10.1126/science.aay1790 2020

Casotti, R., Landolfi, A., Brunet, C., D'Ortenzio, F., Mangoni, O., d'Alcalà, M. R., \& Denis, M. Composition and dynamics of the phytoplankton of the Ionian Sea (eastern Mediterranean). Journal of Geophysical Research: Oceans, 108(C9). 2003

Celentano, P., Falco, P., \& Zambianchi, E. Surface connection between the Ionian Sea and different areas of the Mediterranean derived from drifter data. Deep Sea Research Part I: Oceanographic Research Papers, 166, 103431. 2020

410 Chronis, G., Lykousis, V., Georgopoulos, D., Zervakis, V., Stavrakakis, S., \& Poulos, S. . Suspended particulate matter and nepheloid layers over the southern margin of the Cretan Sea (NE Mediterranean): seasonal distribution and dynamics. Progress in oceanography, 46(2-4), 163-185. https://doi.org/10.1016/S0079-6611(00)00017-3 2000

Civitarese, G., Gačić, M., Lipizer, M., and Eusebi Borzelli, G. L.: On the impact of the Bimodal Oscillating System (BiOS) on the biogeochemistry and biology of the Adriatic and Ionian Seas (Eastern Mediterranean), Biogeosciences, 7, 39873997, https://doi.org/10.5194/bg-7-3987-2010, 2010.

Feliú, G., Pagano, M., Hidalgo, P., \& Carlotti, F. Structure and function of epipelagic mesozooplankton and their response to dust deposition events during the spring PEACETIME cruise in the Mediterranean Sea. Biogeosciences, 17(21), 54175441. 2020

Doglioli, A.M., Nencioli, F., Petrenko, A. A. , Fuda, J.-L., Rougier, G., Grima, N., A software package and hardware tools for in situ experiments in a Lagrangian reference frame. J. Atmos. Ocean. Tech., doi: 10.1175/JTECH-D-12-00183.1. 2013

d'Ortenzio, F., \& d'Alcalà, M. R. On the trophic regimes of the Mediterranean Sea: a satellite analysis. Biogeosciences, 6(2). 2009

d’Ovidio, F., Della Penna, A., Trull, T. W., Nencioli, F., Pujol, M.-I., Rio, M.-H., Park, Y.-H., Cotté, C., Zhou, M., and Blain, S.: The biogeochemical structuring role of horizontal stirring: Lagrangian perspectives on iron delivery downstream of the Kerguelen Plateau, Biogeosciences, 12, 5567-5581, https://doi.org/10.5194/bg-12-5567-2015 2015.

d’Ovidio, F., Fernández, V., Hernández-García, E., and López, C.: Mixing structures in the Mediterranean Sea from finitesize Lyapunov exponents, Geophys. Res. Lett., 31, L17203, doi:10.1029/2004GL020328, 2004.

da Rocha Marcolin, C., Schultes, S., Jackson, G. A., \& Lopes, R. M. . Plankton and seston size spectra estimated by the LOPC and ZooScan in the Abrolhos Bank ecosystem (SE Atlantic). Continental Shelf Research, 70, 74-87. 2013 
https://doi.org/10.5194/bg-2020-481

Preprint. Discussion started: 25 January 2021

(c) Author(s) 2021. CC BY 4.0 License.

\section{(c) (1)}

Espinasse, B., Carlotti, F., Zhou, M., \& Devenon, J. L. . Defining zooplankton habitats in the Gulf of Lion (NW Mediterranean Sea) using size structure and environmental conditions. Marine Ecology Progress Series, 506, 31-46. 2014

Espinasse, B., Basedow, S., Schultes, S., Zhou, M., Berline, L., \& Carlotti, F.. Conditions for assessing zooplankton abundance with LOPC in coastal waters. Progress in Oceanography, 163, 260-270. 2018

Gačić, M., Borzelli, G. E., Civitarese, G., Cardin, V., \& Yari, S. . Can internal processes sustain reversals of the ocean upper circulation? The Ionian Sea example. Geophysical research letters, 37(9). 2010

Gačić, M., G. Civitarese, G. L. Eusebi Borzelli, V. Kovačević, P.-M. Poulain, A. Theocharis, M. Menna, A. Catucci, and N. Zarokanellos, On the relationship between the decadal oscillations of the northern Ionian Sea and the salinity distributions in the eastern Mediterranean, J. Geophys. Res., 116, C12002, doi:10.1029/2011JC007280. 2011

Guidi, L., Stemmann, L., Jackson, G. A., Ibanez, F., Claustre, H., Legendre, L., ... \& Gorskya, G. Effects of phytoplankton community on production, size, and export of large aggregates: A world-ocean analysis. Limnology and Oceanography, 54(6), 1951-1963. 2009

Guieu, C., D'Ortenzio, F., Dulac, F., Taillandier, V., Doglioli, A., Petrenko, A., Barrillon, S., Mallet, M., Nabat, P., and Desboeufs, K.: Introduction: Process studies at the air-sea interface after atmospheric deposition in the Mediterranean Sea - objectives and strategy of the PEACETIME oceanographic campaign (May-June 2017), Biogeosciences, 17, 5563-5585, https://doi.org/10.5194/bg-17-5563-2020, 2020.

Henson, S. A., Sanders, R., Madsen, E., Morris, P. J., Le Moigne, F., \& Quartly, G. D. : A reduced estimate of the strength of the ocean's biological carbon pump. Geophysical Research Letters, 38(4). 2011

450 Herman, A.W., Beanlands, B., Phillips, E.F., The next generation of Optical Plankton Counter: the Laser-OPC. Journal of Plankton Research, 26, 1135-1145. 2004

Herman, A.W., Harvey, M., Application of normalized biomass size spectra to laser optical plankton counter net intercomparisons of zooplankton distributions. Journal of Geophysical Research, 111, 1-9. 2006

Karageorgis, A. P., Gardner, W. D., Georgopoulos, D., Mishonov, A. V., Krasakopoulou, E., \& Anagnostou, C. . Particle dynamics in the Eastern Mediterranean Sea: A synthesis based on light transmission, PMC, and POC archives (19912001). Deep Sea Research Part I: Oceanographic Research Papers, 55(2), 177-202. 2008

Karageorgis, A.P., Georgopoulos, D., Kanellopoulos, T.D., Mikkelsen, O.A., Pagou, K.,Kontoyiannis, H., Kontoyianni, A., Anagnostou, C.: Spatial and seasonal variability of particulate matter optical and size properties in the eastern mediterranean sea. J. Marine Syst. 105, 123-134. 2012

460 Kiko, R : Marine particle size distribution dataset obtained with the Underwater Vision Profiler 5 - Part 1 (2008-2010). https://doi.pangaea.de/10.1594/PANGAEA.924374. 2020

Laurenceau-Cornec, E.C., Le Moigne, F.A.C., Gallinari, M., Moriceau, B., Toullec, J., Iversen, M.H., Engel, A., De La Rocha, C.L.,. New guidelines for the application of Stokes' models to the sinking velocity of marine aggregates. Limnol. Oceanogr. 2019 
https://doi.org/10.5194/bg-2020-481

Preprint. Discussion started: 25 January 2021

(c) Author(s) 2021. CC BY 4.0 License.

\section{(c) (1)}

465 Laurenceau-Cornec, E.C., Trull, T.W., Davies, D.M., Bray, S.G., Doran, J., Planchon, F., Carlotti, F., Jouandet, M.P., Cavagna, A.J., Waite, A.M., Blain, S., The relative importance of phytoplankton aggregates and zooplankton fecal pellets to carbon export: insights from free-drifting sediment trap deployments in naturally iron-fertilised waters near the Kerguelen Plateau. Biogeosciences 12, 1007-1027. 2015.

Lavigne, H., Civitarese, G., Gačić, M., \& D'Ortenzio, F. . Impact of decadal reversals of the north Ionian circulation on phytoplankton phenology. Biogeosciences, 15(14). 2018

Le Bot, P., C. Kermabon, P. Lherminier, F. Gaillard: Rapport technique OPS/LPO 11-01. Ifremer, Centre de Brest, France. https://www.umr-lops.fr/en/Technology/Software/CASCADE-7.2 2011

Le Moigne, F. A. C. . Pathways of organic carbon downward transport by the oceanic biological carbon pump. Frontiers in Marine Science, 6, 634. 2019

475 Le Moigne, F.A.C.; Gallinari, M.; Laurenceau, E.; De La Rocha, C.L.. Enhanced rates of particulate organic matter remineralization by microzooplankton are diminished by added ballast minerals. Biogeosciences, 10 (9). 5755-5765. https://doi.org/10.5194/bg-10-5755-2013. 2013

MacIntyre, S., Alldredge, A.L., Gotschalk, C.C., Accumulation of Marine Snow at Density Discontinuities in the Water Column. Limnology and Oceanography, 40, 449-468. 1995

480 Malanotte-Rizzoli, P., Manca, B. B., d'Alcalà, M. R., Theocharis, A., Bergamasco, A., Bregant, D., ... \& Sansone, E. . A synthesis of the Ionian Sea hydrography, circulation and water mass pathways during POEM-Phase I. Progress in Oceanography, 39(3), 153-204. 1997

Marañón, E., Van Wambeke, F., Uitz, J., Boss, E. S., Pérez-Lorenzo, M., Dinasquet, J., Haëntjens, N., Dimier, C., and Taillandier, V.: Deep maxima of phytoplankton biomass, primary production and bacterial production in the Mediterranean Sea during late spring, Biogeosciences Discuss., https://doi.org/10.5194/bg-2020-261, in review, 2020.

Martin, P., Lampitt, R., Perry, M.J., Sanders, R., Lee, C., D’asaro, E. Export and mesopelagic particle flux during a North Atlantic spring diatom bloom. Deep sea Res. part I 58, 338-349. 2011

Mazzocchi, M. G., Nervegna, D., D'elia, G., Di Capua, I., Aguzzi, L., \& Boldrin, A.. Spring mesozooplankton communities in the epipelagic Ionian Sea in relation to the Eastern Mediterranean Transient. Journal of Geophysical Research: Oceans, 108(C9). 2003

Menna, M., Suarez, N. R., Civitarese, G., Gačić, M., Rubino, A., \& Poulain, P. M. . Decadal variations of circulation in the Central Mediterranean and its interactions with mesoscale gyres. Deep Sea Research Part II: Topical Studies in Oceanography, 164, 14-24. 2019

Moutin, T., Doglioli, A.M., de Verneil, A., Bonnet, S. . Preface: The Oligotrophy to the UlTra-oligotrophy PACific Experiment (OUTPACE cruise, 18 February to 3 April 2015). Biogeosciences, 14, 3207-3220, doi:10.5194/bg-143207-2017. 2017 
https://doi.org/10.5194/bg-2020-481

Preprint. Discussion started: 25 January 2021

(c) Author(s) 2021. CC BY 4.0 License.

\section{(c) (1)}

Nardelli, B. B., Tronconi, C., Pisano, A., \& Santoleri, R.. High and Ultra-High resolution processing of satellite Sea Surface Temperature data over Southern European Seas in the framework of MyOcean project. Remote Sensing of Environment, 129, 1-16. 2013

Ohman, M. D., Powell, J. R., Picheral, M., \& Jensen, D. W.. Mesozooplankton and particulate matter responses to a deepwater frontal system in the southern California Current System. Journal of plankton research, 34(9), 815-827. 2012

Petrenko, A., Doglioli, A.M., Nencioli, F.,Kersalé, M., Hu, Z., d'Ovidio, F.. A review of the LATEX project: mesoscale to submesoscale processes in a coastal environment. Ocean Dynam., doi: 10.1007/s10236-017-1040-9. 2017

Picheral, M., Guidi, L., Stemmann, L., Karl, D. M., Iddaoud, G., \& Gorsky, G. (2010). The Underwater Vision Profiler 5: An advanced instrument for high spatial resolution studies of particle size spectra and zooplankton. Limnology and Oceanography: Methods, 8(9), 462-473.

Pisano, A., Nardelli, B. B., Tronconi, C., \& Santoleri, R. The new Mediterranean optimally interpolated pathfinder AVHRR SST Dataset (1982-2012). Remote Sensing of Environment, 176, 107-116. 2016

Prairie, J. C., Ziervogel, K., Camassa, R., McLaughlin, R. M., White, B. L., Dewald, C., \& Arnosti, C.. Delayed settling of marine snow: Effects of density gradient and particle properties and implications for carbon cycling. Marine Chemistry, 175, 28-38. 2015

Rabitti, S., Bianchi, F., Boldrin, A., Daros, L., Socal, G., \& Totti, C. Particulate matter and phytoplankton in the Ionian Sea. Oceanologica Acta, 17(3), 297-307. 1994

Ramondenc, S., Madeleine, G., Lombard, F., Santinelli, C., Stemmann, L., Gorsky, G., \& Guidi, L. An initial carbon export assessment in the Mediterranean Sea based on drifting sediment traps and the Underwater Vision Profiler data sets. Deep Sea Research Part I: Oceanographic Research Papers, 117, 107-119. 2016

Richardson, T.L., Jackson, G.A.,. Small phytoplankton and carbon export from the surface ocean. Science (80-. ). 315, 838840. https://doi.org/10.1126/science.1133471. 2007

Riley, J., Sanders, R., Marsay, C., Le Moigne, F.A.C., Achterberg, E., Poulton, A., The relative contribution of fast and slow sinking particles to ocean carbon export. Global Biogeochem. Cycles 26. https://doi.org/doi:10.1029/2011GB004085. 2012

Stange, P., Bach, L., Le Moigne, F.A.C., Taucher, J., Boxhammer, T., Riebesell, U.,. Quantifying the time lag between organic matter production and export in the surface ocean: Implications for estimates of export efficiency. Geophys. Res. Lett. https://doi.org/10.1002/2016GL070875. 2017

525 Stemmann L., G., Jackson, G. Gorsky. A vertical model of particle size distributions and fluxes in the midwater column that includes biological and physical processes. II. Application to a three year survey in the NW Mediterranean Sea .Deep Sea Research I 51 (7): 865-884. 2004

Von Schuckmann, K., Le Traon, P. Y., Smith, N., Pascual, A., Djavidnia, S., Gattuso, J. P., ... \& Álvarez Fanjul, E.. Copernicus Marine Service Ocean State Report, Issue 3. Journal of Operational Oceanography, 12(sup1), S1-S123. 2019 
https://doi.org/10.5194/bg-2020-481

Preprint. Discussion started: 25 January 2021

(C) Author(s) 2021. CC BY 4.0 License.

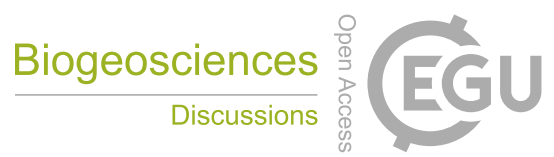

Waite, A. M., Stemmann, L., Guidi, L., Calil, P. H., Hogg, A. M. C., Feng, M., ... \& Gorsky, G. The wineglass effect shapes particle export to the deep ocean in mesoscale eddies. Geophysical Research Letters, 43(18), 9791-9800. 2016 
https://doi.org/10.5194/bg-2020-481

Preprint. Discussion started: 25 January 2021

(c) Author(s) 2021. CC BY 4.0 License.

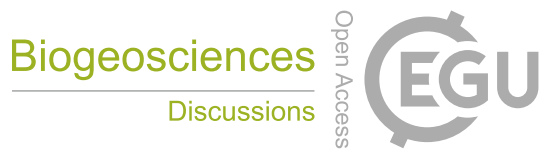

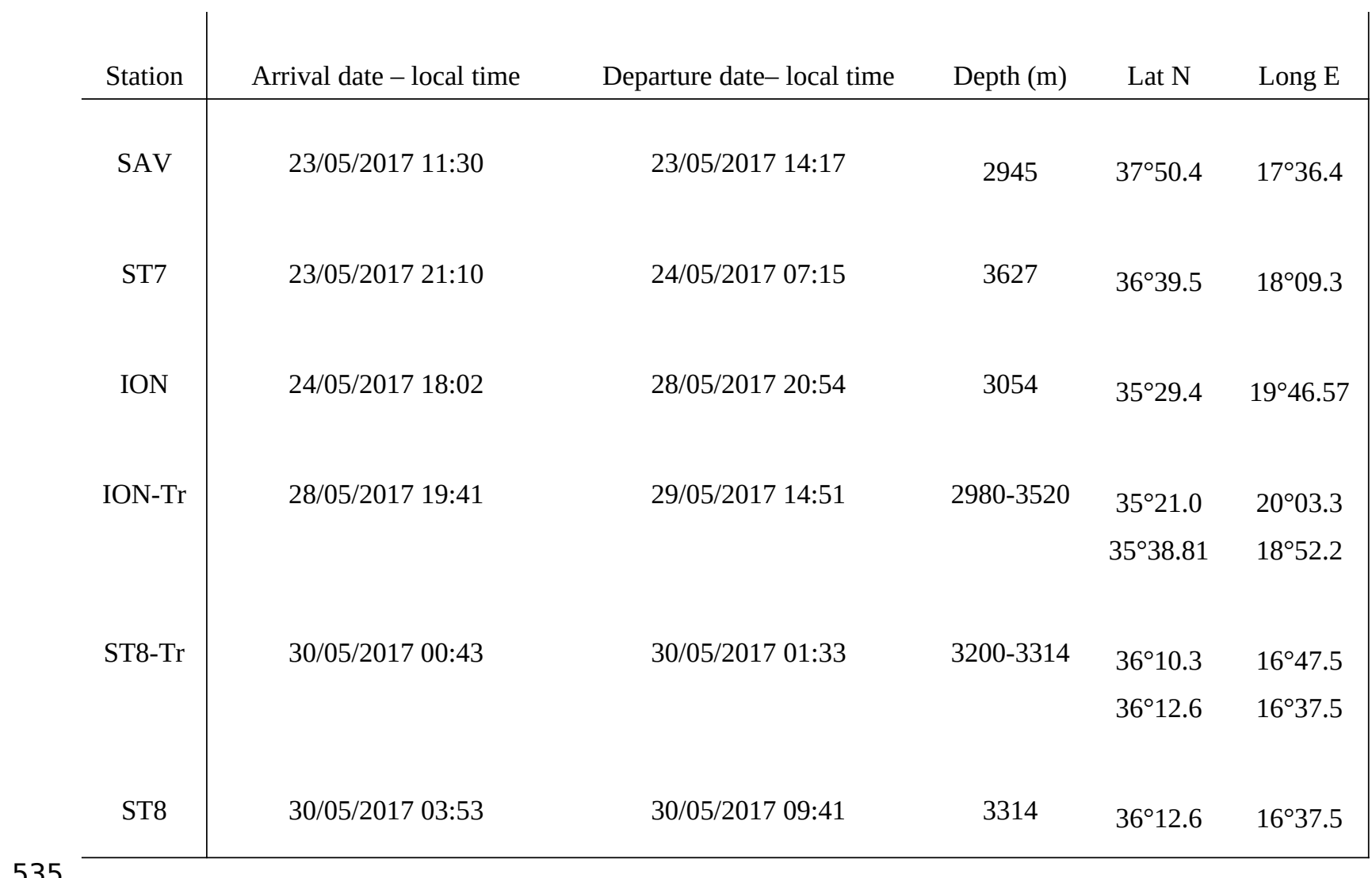

Table 1. Sampling in the Ionian Sea (see figure 1). Note that ST8 and ST8-Tr are considered in the study as one single station. 
https://doi.org/10.5194/bg-2020-481

Preprint. Discussion started: 25 January 2021

(c) Author(s) 2021. CC BY 4.0 License.

\begin{tabular}{|c|c|c|c|c|c|}
\hline & ION-W (n=13) & ION-C $(n=10)$ & ION-E $(n=15)$ & ST8 $(n=8)$ & SAV $(n=15)$ \\
\hline \multicolumn{6}{|l|}{$5-50 \mathrm{~m}$} \\
\hline \%МЕP & $0.35(0.2-0.5)$ & $0.53(0.2-0.8)$ & $1.23(0.6-1.8)$ & $0.87(0.4-1.3)$ & $3.20(2.1-5.6)$ \\
\hline AI & $0.05(0.03-0.16)$ & $0.08(0.04-0.12)$ & $0.10(0.07-0.15)$ & $0.15(0.08-0.24)$ & $0.08(0.07-0.10)$ \\
\hline \%detritus & 16.08 & 26.46 & 47.54 & 38.87 & 71.47 \\
\hline \multicolumn{6}{|l|}{$50-150 \mathrm{~m}$} \\
\hline \%MEP & $1.26(0.8-2.0)$ & $1.29(0.9-1.7)$ & $7.76(4.7-9.1)$ & $6.08(3.7-7.4)$ & $4.44(3.4-7.4)$ \\
\hline AI & $0.05(0.04-0.11)$ & $0.08(0.04-0.11)$ & $0.10(0.09-0.11)$ & $0.10(0.08-0.14)$ & $0.08(0.07-0.10)$ \\
\hline \%detritus & 48.14 & 48.73 & 93.64 & 87.53 & 79.67 \\
\hline \multicolumn{6}{|l|}{$150-300 \mathrm{~m}$} \\
\hline \%MEP & $1.17(0.7-1.6)$ & $1.00(0.6-1.25)$ & $5.68(2.0-7.5)$ & $2.24(1.5-3.4)$ & $2.94(1.8-4.2)$ \\
\hline AI & $0.05(0.03-0.16)$ & $0.07(0.03-0.13)$ & $0.11(0.07-0.14)$ & $0.16(0.09-0.25)$ & $0.08(0.06-0.11)$ \\
\hline \%detritus & 46.28 & 42.36 & 85.83 & 62.54 & 69.35 \\
\hline \multicolumn{6}{|l|}{$5-300 \mathrm{~m}$} \\
\hline \%MEP & $0.84(0.51-1.16)$ & $0.93(0.64-1.08)$ & 5.98 (3.39-7.29) & $4.83(2.98-5.97)$ & $3.81(2.9-5.7)$ \\
\hline AI & $0.05(0.04-0.12)$ & $0.08(0.04-0.12)$ & $0.10(0.09-0.12)$ & $0.11(0.08-0.15)$ & $0.08(0.07-0.10)$ \\
\hline \%detritus & 37.99 & 40.54 & 87.12 & 81.77 & 75.84 \\
\hline Abund $\mathrm{m}^{-3} \times 10^{4}$ & $1.17(0.84-2.28)$ & $1.17(0.70-1.50)$ & $1.85(1.46-2.09)$ & $3.71(2.63-6.86)$ & $5.43(3.30-8.35)$ \\
\hline BioV $\mathrm{mm}^{3} \mathrm{~m}^{-3} \times 10^{3}$ & $0.36(0.15-1.25)$ & $0.39(0.18-1.33)$ & $0.81(0.38-1.20)$ & $1.54(0.81-2.69)$ & $2.58(1.42-3.56)$ \\
\hline NBSS & $y=-0.93 x+3.95$ & $y=-0.91 x+4.02$ & $y=-0.85 x+4.26$ & $y=-0.92 x+4.58$ & $y=-0.86 x+4.76$ \\
\hline
\end{tabular}

Table 2. LOPC particle derived parameters for ION-Tr, ST8 and SAV, for three depth layers. Abund : Total abundance and BioV : total biovolume. 
https://doi.org/10.5194/bg-2020-481

Preprint. Discussion started: 25 January 2021

(c) Author(s) 2021. CC BY 4.0 License.

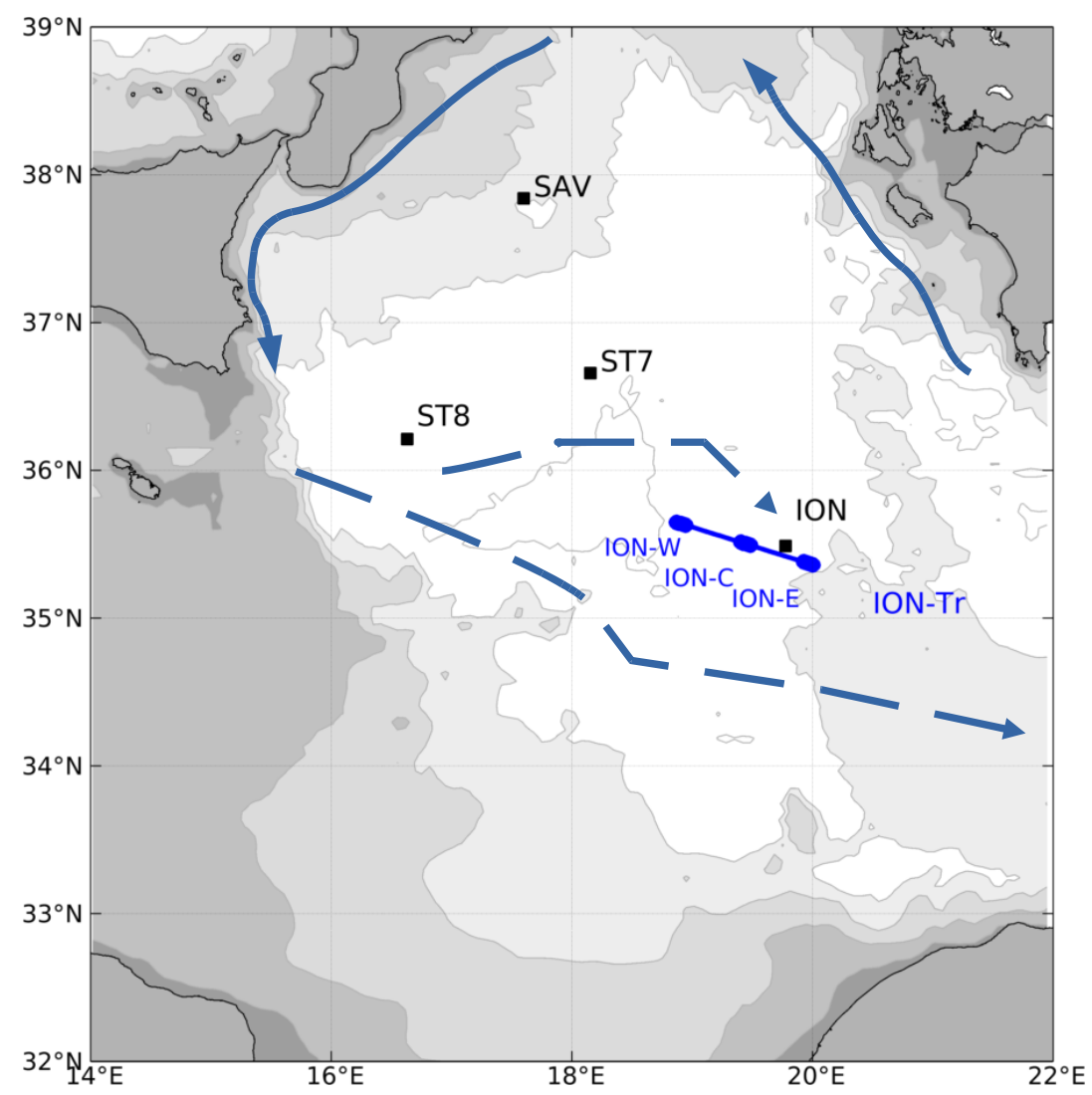

Figure 1. Bathymetry of the Ionian Sea (isobaths 100, 1000, 2000, 3000, 4000m) with the locations of stations (black squares), transect and transect parts (blue line and dots). Schematic circulation (dark blue arrows) for cyclonic conditions redrawn from Menna et al (2019). 
https://doi.org/10.5194/bg-2020-481

Preprint. Discussion started: 25 January 2021

(c) Author(s) 2021. CC BY 4.0 License.

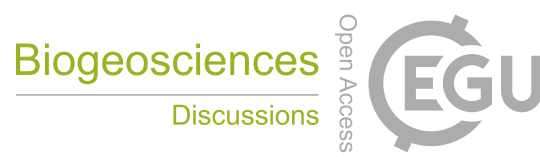

(c) (1)
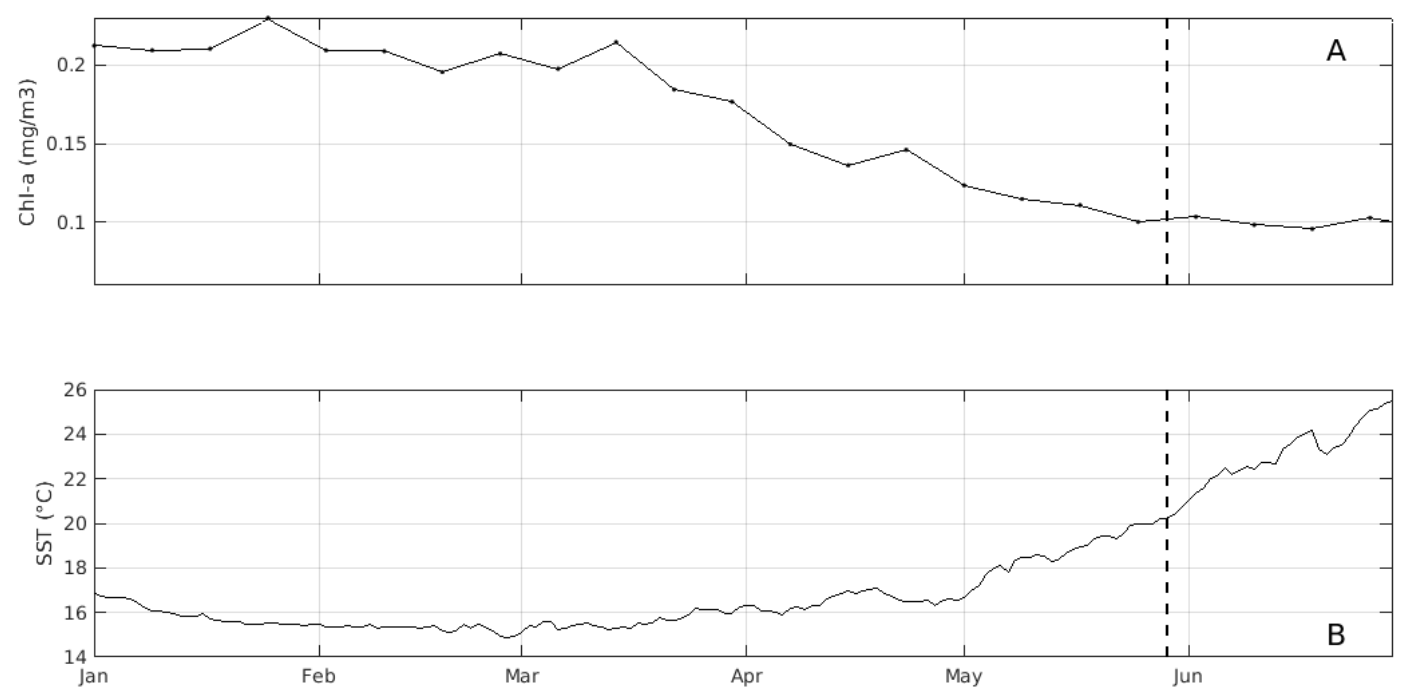

550 Figure 2 : Time series of A) 8-day satellite Chl-a and B) daily SST prior to sampling, averaged over the northern Ionian Sea (16 ${ }^{\circ}$ to $22^{\circ} \mathrm{E}, 33^{\circ}$ to $40^{\circ} \mathrm{N}$ ). Sampling at ION-Tr is marked by the dashed vertical line. 
https://doi.org/10.5194/bg-2020-481

Preprint. Discussion started: 25 January 2021

(c) Author(s) 2021. CC BY 4.0 License.
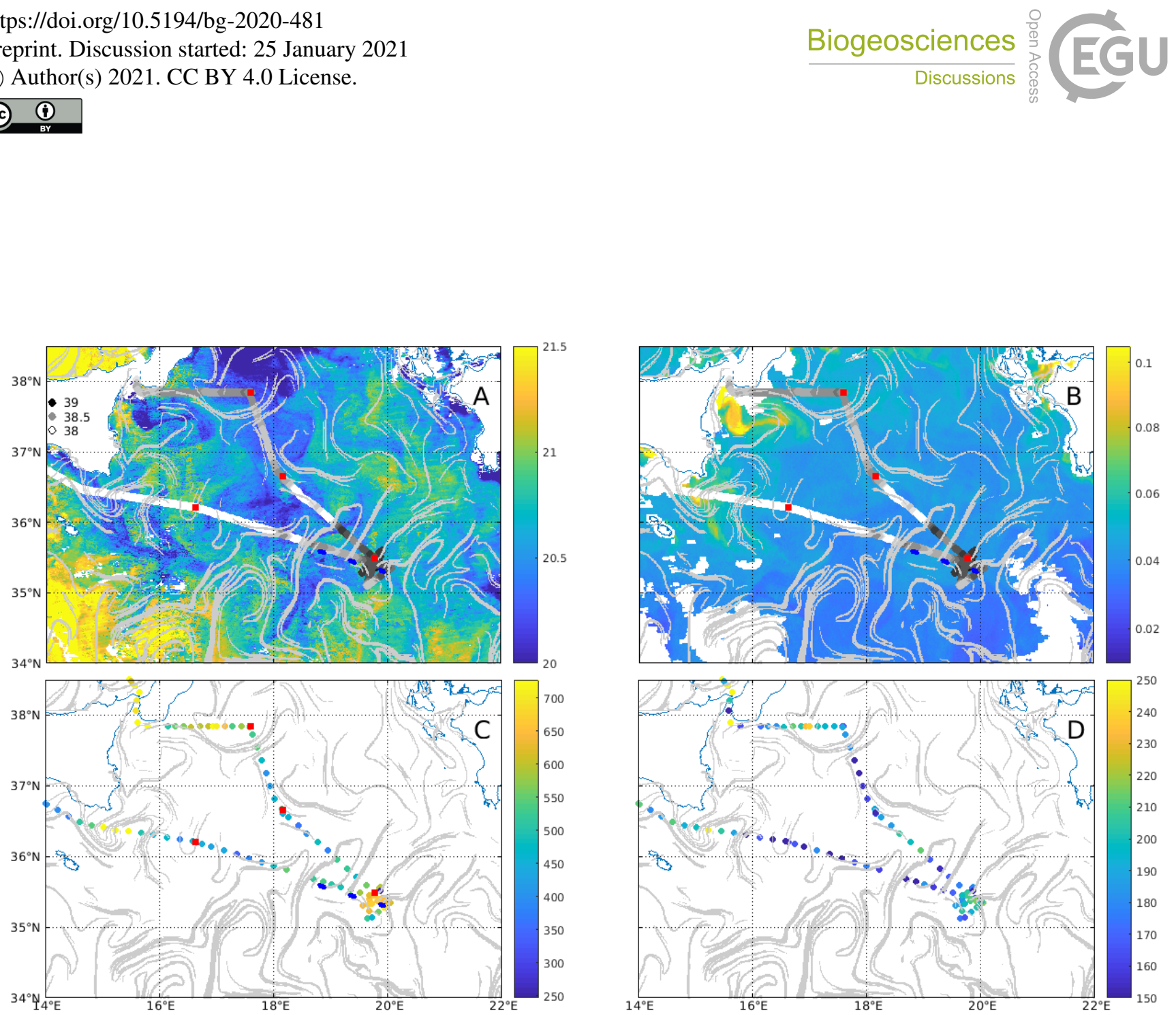

Figure 3. A) Satellite SST (May 29-30 ${ }^{\text {th }}$, night, $\left.{ }^{\circ} \mathrm{C}\right)$. B) Chl-a $\left(\mathrm{May} 30^{\text {th }}, \mathrm{mg} / \mathrm{m}^{3}\right)$. On panels A and B, underway surface salinity from

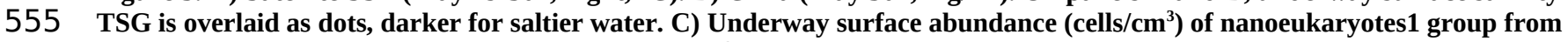

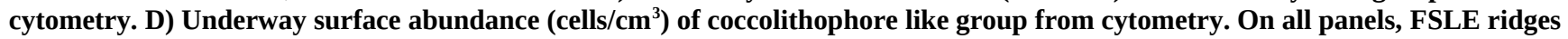
are overimposed in light grey $\left(>0,15\right.$ day $\left.^{-1}\right)$. Stations positions are marked as red squares and ION-Tr parts as blue dots as figure 1 . 
https://doi.org/10.5194/bg-2020-481

Preprint. Discussion started: 25 January 2021

(c) Author(s) 2021. CC BY 4.0 License.

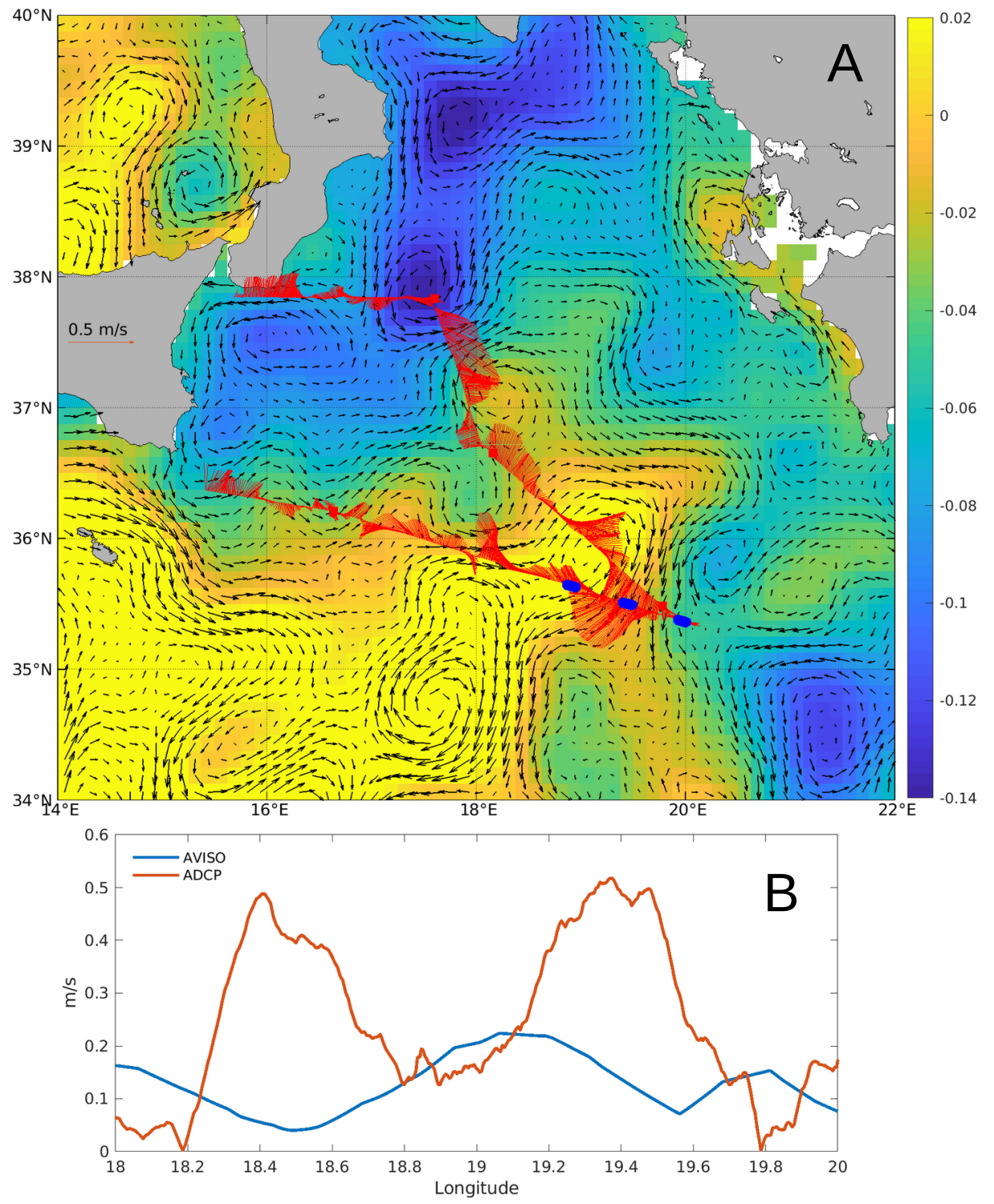

Figure 4. A) Absolute Dynamic Topography (ADT, color) and surface geostrophic circulation from altimetry averaged over period May 22-30 ${ }^{\text {th }}$ (black arrows). Underway ADCP currents are overlaid (red arrows). ION-Tr parts marked as blue dots as figure 1. B) Velocity along ION-Tr transect derived from altimetry for May $29^{\text {th }}$ and measured with ADCP . 

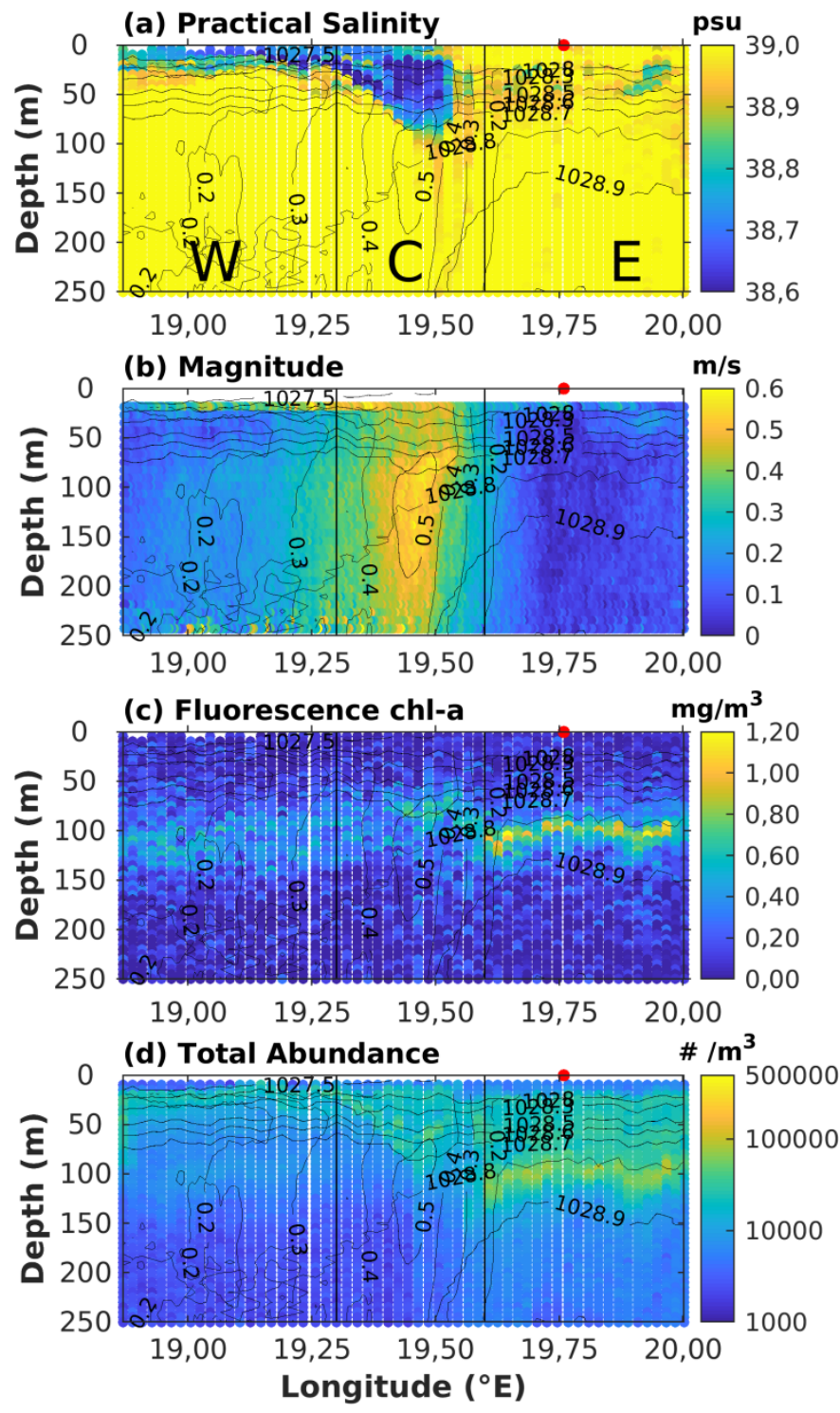

Figure 5. Variables sampled along ION-Tr transect from MVP, plotted as depth vs longitude. a) Salinity, b) ADCP current magnitude, c) Fluorescence and d) Total particle abundance. Density and current magnitude are overlaid as black contours on all panels. The three parts of the transect where ION-W, ION-C, ION-E pseudo-stations are located are delimited by black vertical lines. ION station position is marked as red dot on top of each panel. 
https://doi.org/10.5194/bg-2020-481

Preprint. Discussion started: 25 January 2021

(c) Author(s) 2021. CC BY 4.0 License.
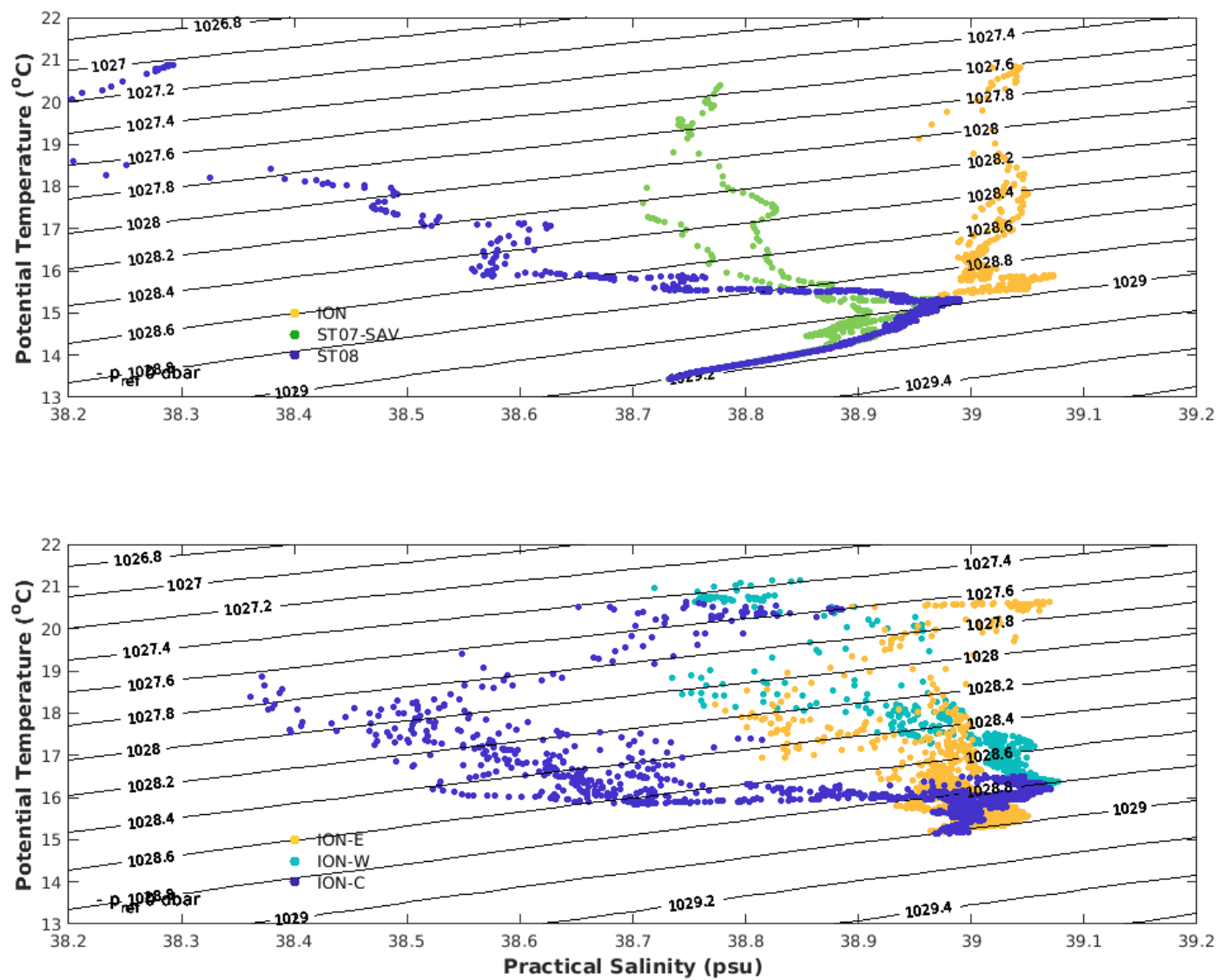

Figure 6. TS-diagram for stations ION, SAV, ST7, ST8 (top) and for ION-Tr parts (bottom), ION-W, ION-C, ION-E. 
https://doi.org/10.5194/bg-2020-481

Preprint. Discussion started: 25 January 2021

(c) Author(s) 2021. CC BY 4.0 License.
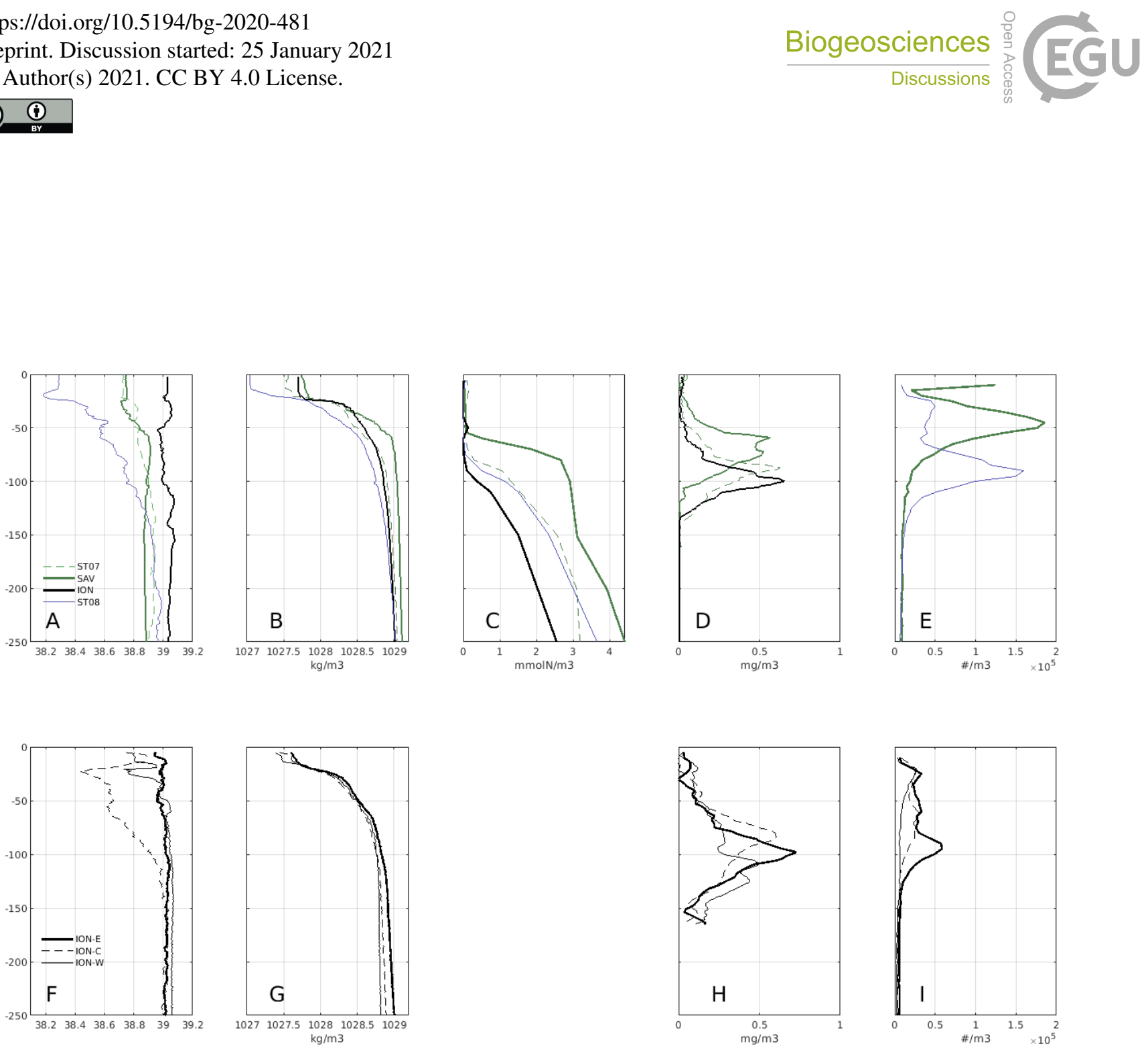

Figure 7. Vertical profiles of variables at ION, SAV, ST7, ST8 (top) and for ION-Tr parts (bottom), ION-W, ION-C, ION-E. quantified at ST7. 

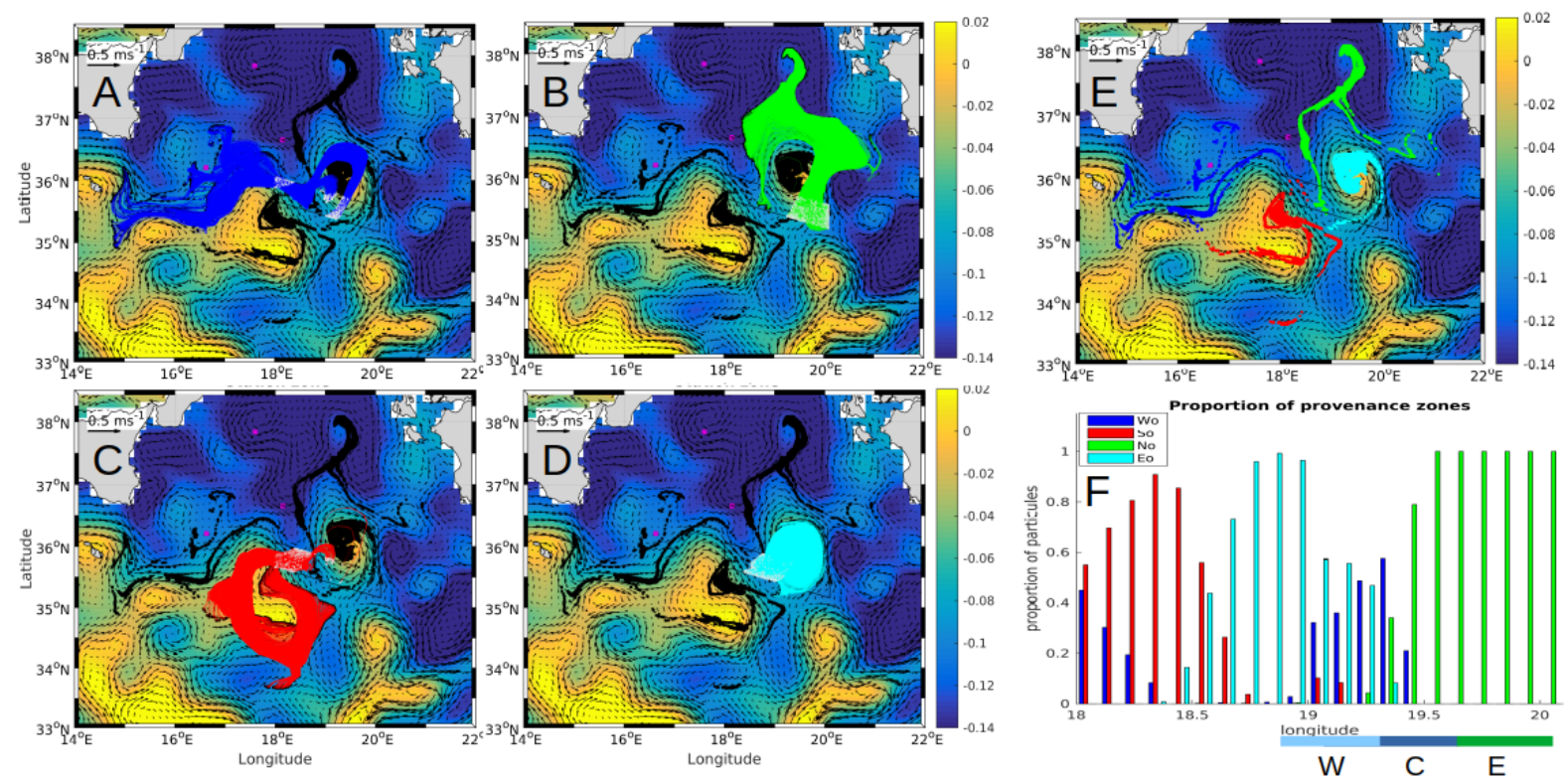

Figure 8. Backward Lagrangian trajectories for particles launched along ION transect and tracked for one month, with average ADT and surface currents averaged for period May $1-30^{\text {th }}$. Trajectories are separated according to the four major origins. panel A for Wo, B for No, C for So, D for Eo. Black dots are the final positions. E) Final positions of particles for each origin. F) Proportion of each origin along ION-Tr computed for each $0.1^{\circ}$ of longitude. The three parts of ION-Tr shown on figure 5 are plotted at the bottom.

Supplementary material

https://people.mio.osupytheas.fr/ berline.1/movie_ADT.gif

Appendix A. Absolute Dynamic Topography evolution for period Jan $1^{\text {st }}-J u n e ~ 15^{\text {th }} 2017$. Ship track is marked as thin black line and ION-Tr as thick black line. The anticyclonic eddy sampled during ION-Tr is visible during the whole period. 